\title{
Criança, terreiro e aprendizagem: um olhar sobre a infância no candomblé
}

\author{
Amurabi Oliveira* \\ Kleverton Arthur Almirante*
}

\section{Resumo}

As pesquisas no campo da Antropologia da Criança ainda são incipientes quanto aos estudos envolvendo as crianças de Candomblé, especialmente no que diz respeito aos seus processos de aprendizagem. O presente trabalho é elaborado na interface entre a Antropologia da Educação, da Criança e da Religião, visando investigar o que é ser criança no Candomblé e a forma como se constituem os processos de aprendizagem das crianças no terreiro, como na recorrência à brincadeira e à ludicidade nesses processos. Os dados exibidos são oriundos da pesquisa etnográfica que foi realizada entre os anos de 2013 e 2014, na cidade de Maceió - Alagoas.

Palavras-chave: Antropologia da Criança. Criança de Candomblé. Aprendizagem nos Terreiros.

\section{Child, terreiro and learning: a look at the childhood in can- domblé}

\section{Abstract}

All the research in the field of Child Anthropology are still incipient for the studies involving children of Candomblé, especially with regard to their learning processes. This work is developed at the interface between the Anthropology of Education, Children and Religion, to investigate what being a child in Candomble and how they are the learning processes of children in the terreiro, as the recurrence to play and playfulness in these processes. The data presented are from ethnographic research that was developed between the years 2013 and 2014, in the city of Maceió - Alagoas.

Key-words: Anthropology of the Child. Child of Candomblé. Learning in Terreiros.

\footnotetext{
* Licenciado e Mestre em Ciências Sociais (UFCG), Doutor em Sociologia (UFPE), professor da Universidade Federal de Santa Catarina, atuante em seu Programa de Pós-Graduação em Sociologia Política. Pesquisador do CNPq. E-mail: amurabi_cs@hotmail.com

** Mestre em educação pela Universidade Federal de Alagoas. E-mail: kleverton.almirante@, cedu.ufal.br
} 


\section{Niño, terrero y aprendizaje: una mirada sobre la infancia en el candomblé}

\section{Resumen}

Las investigaciones en el campo de la Antropología de la Niñez aún son incipientes, bien como los estudios involucrando a los niños de Candomblé, especialmente en lo que se refiere a sus procesos de aprendizaje. El presente trabajo es elaborado en la interfaz entre la Antropología de la Educación, de la Niñez y de la Religión, buscando investigar lo que es ser niño en el Candomblé y la forma como se constituyen los procesos de aprendizaje de los niños en el terreiro, y la presencia de la broma y de la ludicidad en estos procesos. Los datos presentados son oriundos de la investigación etnográfica que se realizó entre los años de 2013 y 2014, en la ciudad de Maceió - Alagoas.

Palabras clave: Antropología de la Niñez. Niño de Candomblé. Aprendizaje en los Terreros.

\section{Introdução}

Nos últimos anos, a Antropologia tem ampliado seu leque de questões, bem como, a respeito de quais sujeitos ela direciona o seu olhar. Todavia, há pouco mais de uma década, Hirschfel (2002) ${ }^{1}$ lançou uma pergunta bastante instigante, ao questionar "por que os antropólogos não gostam de crianças?", ao mesmo tempo em que problematizava a perspectiva "adultocêntrica" amplamente difundida nessa ciência.

Acreditamos que há um movimento, dentro da ciência antropológica, para responder à pergunta de Hirschfel, de tal modo que o amadurecimento do campo "Antropologia da Criança" busca romper com essa perspectiva "adultocêntrica" de mundo. Em princípio, compreendendo as crianças como agentes e produtoras de cultura.

Nessa direção, Pires (2010) indica que os conceitos de cultura e sociedade, implicados na noção de socialização, tal como vinham sendo elaborados, não dariam conta do que se passa no mundo adulto, nem no mundo infantil. Os avanços que ocorrem no campo da Antropologia da Criança têm sido forjados na interface com outros campos, como os campos da Antropologia da Educação, do Corpo, da Religião etc.

O presente trabalho desenvolveu-se justamente entre a Antropologia da Criança, da Educação e da Religião. E aqui pretendemos refletir acerca da infância no Candomblé e as formas de aprendizagem vivenciadas pelas crianças no terreiro. É no cerne das investigações na Antropologia da Crian-

\footnotetext{
1 O autor afirma que as crianças possuiriam uma "arquitetura mental" que lhes permite
} compreender o mundo de uma forma mais acurada que os adultos. 
ça que o aprendizado no Candomblé e a forma como são desenvolvidas as brincadeiras se fizeram evidentes.

O papel da ludicidade em todo o processo de aprendizagem das crianças de Candomblé foi verificado no trabalho de campo realizado em dois terreiros intimamente ligados, localizados na periferia da cidade de Maceió - Alagoas, entre os anos de 2013 e 2014.

É importante destacar que, apesar das investigações sobre as religiões afro-brasileiras serem com frequência exploradas na Antropologia da Religião no Brasil, ainda são poucas as pesquisas voltadas para pensar a educação nos terreiros a partir das perspectivas das crianças, que, via de regra, são pouco visibilizadas em pesquisas anteriores. ${ }^{2}$

Para uma melhor compreensão dos resultados da pesquisa, aqui explanados, apresentaremos o texto na seguinte ordem: breve contextualização a respeito das religiões afro-brasileiras em Alagoas; contexto no qual a pesquisa foi realizada, o que se segue de uma reflexão sobre a infância no Candomblé e é complementado pela apresentação das crianças na pesquisa; por fim, como pensamos o terreiro, espaço de aprendizagem, e o que é operacionalizado nele, principalmente, por meio da brincadeira.

\section{As religiões afro-brasileiras em Alagoas}

O campo de pesquisas sobre as religiões afro-brasileiras no Brasil é marcado por uma série de tensões que envolvem os processos históricos de invisibilização das populações negras na sociedade brasileira. Ao lado desse processo, pese-se o processo de "desetnização"3 dessas religiões (PRANDI, 2004) e a presença crescentemente massiva tanto de "elementos brancos" em seus rituais, quanto de praticantes brancos (ORTIZ, 1999).

Para além das questões mais amplas, isto é, nacionalmente, há de se reconhecer as idiossincrasias que envolvem práticas em realidades distintas. Nesse sentido, acreditamos que é relevante destacar algumas marcas dessas religiões em Alagoas.

2 Mesmo as crianças ocupando os espaços dos terreiros e, em muitos casos, desempenhando funções ritualísticas, posições de comando, como indicam as pesquisas realizadas por Falcão (2010) e Caputo (2012).

3 Compreende-se com isso o processo de passagem dessas religiões da condição de étnicas - ou seja, uma religião que atende a demandas próprias que um dado grupo étnico pertencendo a este - para a condição de religião universal, nos termos postos por Weber (1982). Nesse sentido, uma religião universal é aquela que produz determinadas regras de vida e consegue reagrupar em torno de uma ideia religiosa ou de uma moral religiosa uma massa de fiéis. 
Apesar de ser um Estado com uma presença negra evidente, em termos étnicos e culturais há uma forte negação dessa identidade, o que inclui as religiões afro-brasileiras, especialmente o Xangô, como são conhecidas algumas vertentes de culto nagotizadas do Candomblé em Alagoas e Pernambuco (RIBEIRO, 1982).

$\mathrm{O}$ ápice do violento processo de negação da identidade negra em Alagoas remete ao acontecimento do "Quebra de Xangô", ou simplesmente "Quebra", que ocorreu em fevereiro de 1912. O evento se inseriu em meio às tensões políticas postas na República Velha, uma vez que a perseguição e a destruição dos principais terreiros de Maceió ocorreram face à perseguição política ao governador Euclides Malta, que seria frequentador de terreiros, xangozeiro, filho de Leba - designativo de origem jeje correspondente ao orixá nagô Exu (I. SANTOS, 2014).

Os episódios de perseguição e destruição resultaram numa maior invisibilização da cultura negra nas práticas populares alagoanas, além da dispersão de inúmeras lideranças religiosas que procuraram refúgio em Estados próximos, como Pernambuco e Bahia, ou mesmo em locais mais distantes, como o Rio de Janeiro.

Nesse cenário, surgiu o que ficou conhecido como "xangô-reazado-baixo", modalidade de cultos sem o aparato ritualístico musical e dançante do passado, temendo alguma forma de repressão (RAFAEL, 2010).

Tendo em vista a magnitude do episódio aqui brevemente narrado, ${ }^{4}$ afirmamos que é impossível compreender a dinâmica da identidade religiosa afro-brasileira em Alagoas, na escola e em outros espaços, sem ter em mente tais questões. $\mathrm{O}$ violento processo vivenciado no começo do século XX emoldura os dilemas da identidade religiosa no Estado. [...]

O episódio do "Quebra" afetou de forma mais incisiva os cultos afro-brasileiros em Alagoas, mas não apenas estes, tendo em vista que a identidade cultural é sempre relacional (WOODWARD, 2009), e que, portanto, a compreensão em torno do "eu" está intimamente relacionada com a do "outro".

4 De acordo com os relatos históricos, percebemos que o "Quebra" foi sobretudo um evento político, marcado pela disputa entre a oposição e o governador Euclides Vieira Malta (2861-1944), supostamente ligado às religiões afro-brasileiras (conhecidos na região como Xangôs), com destaque para a série de reportagens do "Jornal de Alagoas" intitulada "Bruxaria”. O ápice do episódio se dá em 1. de fevereiro de 1912, quando uma milícia armada denominada "Liga dos Republicanos Combatentes" invade e destrói os principais terreiros da cidade. Para uma melhor análise do "Quebra", veja Rafael (2012) e I. Santos (2014). 
Podemos afirmar, partindo desta perspectiva, que o "Quebra" alterou a forma de se pensar as religiões como um todo, e a forma de interpretar os diálogos possíveis entre as diversas matrizes religiosas (OLIVEIRA; ALMIRANTE; SANTOS, 2013, p. 269).

Ainda que se trate de algo ocorrido há mais de um século, acreditamos que essa é uma questão relevante para ser posta, uma vez que impacta o processo de invisibilização das religiões afro-brasileiras em Alagoas, especialmente nos espaços públicos, como a própria escola.

Todavia, não queremos afirmar, com isso, que estamos diante de uma realidade estática, ao contrário, pois as religiões afro-brasileiras encontram-se em contínuo processo de negociação e vêm se dinamizando a partir de diversos dispositivos. Devido ao limite deste trabalho, este ponto não será aprofundado neste momento.

\section{Contextualizando a pesquisa}

A pesquisa da qual tratamos foi realizada no terreiro Axé Vodun Tó Yeyê Apará, uma casa de candomblé regida pela divindade aquática de origem nagô-iorubá Oxum. Esse terreiro localiza-se numa região de difícil acesso, por estradas de barro, de um dos bairros periféricos da cidade de Maceió - o bairro do Tabuleiro do Martins. É importante frisar que um dos autores deste texto pertence a essa casa, o que faz que a todo o tempo haja um contínuo exercício de estranhamento dessa realidade, buscando desnaturalizá-la, ao mesmo tempo em que o pertencimento facilitou o acesso à casa e às crianças que nela circulam.

A casa de axé, como também é chamado um terreiro de candomblé, é dirigida pelo zelador de culto Marcos de Apará, conhecido pelo hierônimo Aparálòmi - que significa que Oxum recebe o raio nas águas - e pela mãe-pequena Sandra de Aganjú, conhecida como Obágànjèní - que significa que Aganjú é o rei das lavas vulcânicas [correntes de fogo]. Nessa localização atual, sua forma espacial data do ano de 2007, conquanto que seu $a x e^{5}$ remonta ao ano de $1979,{ }^{6}$ e que a partir daí logrou mais duas localizações (reinaugurações de axé), sendo a segunda em 1999.

O espaço físico do terreiro é profundamente marcado pelos vínculos familiares, e compreende tanto a família-de-santo, quanto a família biológica. ${ }^{7}$

5 Segundo Bastide (2001, p. 308) "Axé: este termo corresponde mais ou menos ao que os sociólogos chamam mana e é sempre empregado, não para designar uma força impessoal, mas para certas espécies de encarnação de forças (ervas, alicerces do candomblé etc.)".

6 A casa de axé foi inaugurada em 1979, no bairro de Bebedouro, reinaugurada no bairro atual em 1999 e teve seu axé reinaugurado em outra casa do mesmo bairro em 2007.

Apesar da relevância da discussão sobre famílias de santo, não é possível abordar 
As casas próximas são de sujeitos que possuem vínculos com o terreiro, o que faz que a rua também seja um espaço de socialização e ritualístico.

As obrigações para integrar o corpo iniciático da casa se dão com a raspagem da cabeça e reclusão mínima de 21 dias de aprendizado, antecipada com os ebós ${ }^{8}$ de limpeza, o apanhado das folhas usadas para a produção dos banhos e chás, o culto à cabeça do iniciando, o sacrifício de animais, o ensino da linguagem comunicativa e da expressão dançante, os preparativos para a festa de saída culminante da reclusão, que finda após esses 21 dias, além de afazeres diários domésticos, como cozinhar, lavar roupas, varrer etc.

Das várias crianças que abraçam o Candomblé nessa casa, duas se mostraram casos emblemáticos para os resultados preliminares da pesquisa, são ekédji W., que, no início da pesquisa, era uma abiyã (neófita não raspada) que ainda não havia sido apontada pelo santo como ekédji, e Y. Iyadolomí, uma vodunsi, isto é, foi raspada como iyawô há mais de um ano. Ambas não integram mais esse terreiro. Agora elas fazem parte de um novo terreiro, espécime de filial da matriz que é o Tó Apará. No dia 3 de novembro de 2013, o pai de santo delas, irmão de santo de um dos autores deste trabalho, inaugurou sua casa de candomblé, dando a ela o nome de Ilê Aiyê Axé Odé Mitaquassy. ${ }^{9}$

Ekédji W. e Y. Iyadolomi se mostraram casos emblemáticos, justamente entre outras razões, por serem bastante desinibidas durante a pesquisa. As demais crianças do Tó Apará, um total de cinco atualmente, constituíram um processo contínuo de conquista ao longo da pesquisa, de tal modo que, neste trabalho, não utilizamos os dados obtidos com todas elas, mas apenas aqueles que consideramos mais completos.

Quando a pesquisa de campo foi iniciada, ekédji W. e Y. Iyadolomi eram as mais participantes nos rituais de candomble e tinham maior liberdade para brincar nas horas vagas no terreiro, talvez pela maior participação nos rituais que as outras crianças. Y. Iyadolomí, de 12 anos de idade, é a mais falante e, de todas as crianças, mesmo quando era membro do Tó Apará, quanto agora no Axé Mitaquassy, é a única raspada. Ekédji W., de 9 anos de idade ainda aguarda a

tal questão neste artigo devido aos limites e ao foco deste trabalho.

8 A palavra ebó, do iorubá, significa sacrifício de culto. O sufixo bó deriva de obó/umbó, que significa adoração, culto. Ex.: a palavra borí é a contração de ebó orí, culto/sacrifício/ adoração à cabeça.

9 Essa casa de candomblé é regida pelo vodum Odé, conhecido no Candomblé Ketu como orixá Oxóssi. (Tanto "Odé" quanto "Oxóssi” são termos igualmente empregados nos candomblés de matriz nagô ou iorubá.) A casa está localizada no bairro de Chã da Jaqueira, e o acesso a ela é mais urbanizado que ao Tó Apará. Nela, conseguimos conquistar o envolvimento de mais uma criança para a pesquisa, o ogã $\mathrm{E}$. 
oportunidade de ser uma filha de santo raspada, ${ }^{10}$ pois logo após a inauguração do Axé Mitaquassy, ela foi suspensa como ekédji pelo santo da casa - Odé a escolheu como auxiliar enquanto estivesse virado no pai de santo, pois ela não é virante. ${ }^{11}$

As crianças desta pesquisa são crianças que têm um nome civil e um nome religioso. Os nomes religiosos podem ser: 1) o nome iniciático, que recebem quando são raspadas; 2) o nome funcional pelo qual também são conhecidas - se forem iyawôs, ou vodunsis, carregarão termos que as identifiquem pela ordem de recolhimento no qual foram raspadas; ou mesmo abiãs, que não são ainda raspadas, mas suspensas para algum cargo por algum santo dos dirigentes do terreiro.

A ordem do recolhimento para a raspagem da cabeça também exerce uma função de identificação fortemente marcante. No Tó Apará e no Axé Mitaquassy, o recolhimento de duas ou mais pessoas, podendo ser até de 12 recolhidos para raspar, chama-se barco. Quando alguém é recolhido sozinho para ser raspado, sua identificação será somente a de dofono. A ordem do barco é esta: primeiro dofono (a), segundo dofonitinho (a), depois fomo (a), fomutinho (a), gamo, gamutinho (a), domo, domutinho (a), vimo, vimutinho (a), timo e timutinho (a) que é o décimo segundo do barco, ${ }^{12}$ o último a ser raspado quando começa o ritual da raspagem.

10 A raspagem da cabeça é um ritual de origem iorubá incorporado às culturas de voduns desde o território africano, devido às práticas interculturais já registradas antes da vinda dos africanos ao Novo Mundo. No Brasil, a obrigatoriedade de raspar a cabeça para se consolidar como filho de santo com laços de parentesco estabelecidos na casa se dá porque a iniciação é vista como um nascimento para uma nova vida, desta vez dedicada às coisas do santo do iniciando e do santo da casa. A crença de que o recém-nascido tende a vir ao mundo sem cabelos e, conforme seu crescimento, vão nascendo seus pelos é uma forma de explicar a prática. Outra forma se dá na crença do plantio do axé: a cabeça é vista como um território a ser lavrado e, [no] ao seu centro, são plantadas substâncias mágicas próprias do santo ao qual se está iniciando. Várias explicações simbólicas integram a prática da raspagem da cabeça (BASTIDE, 2001).

11 Equivale dizer que o santo não vira na cabeça dela, isto é, não se manifesta pelo seu corpo.

12 Ser raspado em Jeje é se tornar um fon propriamente dito. Dofono, dófonnù, significa, em língua fongbé, que é a língua materna do Candomblé Jeje, "aquele que está mais perto para nascer como um do povo fon". Dofonitinho, dófonnitín, é "aquele que não está tão perto assim para nascer como um do povo fon". Fomo, fonmù, é "longe de se tornar fon". Fomutinho, fonmùtín, é "tão longe de se tornar fon". Gamo, ganmù, é "este chefia os que estão longe", ou seja, porque está mais longe ainda. Gamotinho, ganmùtín, é "tão mais chefe dos que estão longe". Domo, dómù, é "longe de nascer", porque a raspagem é tida como um novo nascimento para a pessoa e o domo será raspado em sétimo lugar. Domutinho, dómùtín, é "tão mais longe de nascer". Vimo, vimù, é "está longe até de receber o $v i$ ", isto é, o obi, porque para se raspar, primeiro deve haver a cerimônia do obí na cabeça durante o borí que antecede em três a quatro dias a raspagem. Vimutinho, vímùtín, é "tão mais longe até de receber o obì". Timo, tínmù, é "o mais longe". Timutinho, tínmùtín, é "o tão mais longe". Esta representa a ordem do barco seguida nos dois candomblés jejes, o Tó Apará e o Axé Mitaquassy. 
Assim, com todas as nomenclaturas já ditas, as pessoas num terreiro poderão ser, por exemplo, ogã Reginaldo, ekédji Clarize, dofono Gilberto, Luzia Oyasesí (nome de registro em cartório e nome iniciático religioso), fomo Maria, Gamo Jonas Obalokê (nome de identificação pela ordem na qual foi raspado, nome de registro em cartório e nome iniciático que recebeu depois de raspar a cabeça na religião) e uma infinidade de possibilidades de se chamarem as pessoas da religião.

\section{A infância no candomblé}

As crianças desta pesquisa foram encontradas inicialmente no terreiro Axé Vodum Tó Yeyê Apará. [Como já dito] do Tó Apará surgiu o Ilê Aiyê Axé Odé Mitaquassy, terreiro onde agora essas crianças são membros, mas mantêm estreitas ligações com [o primeiro] a casa de candomblé inicial.

O Axé Mitaquassy é um terreiro que segue os mesmos princípios do Tó Apará, a mesma nação Jeje Bravum, ${ }^{13}$ com a diferença de uma característica nagô ainda mais acentuada em alguns aspectos litúrgicos de suas festas. Essa diferença é explicada pelas ligações amigáveis com outras casas de Candomblé Nagô pelas quais seu dirigente, o sacerdote Valmir Pereira Mitaquassy, tem forte apreço. A falecida mãe de santo que dirigia esse terreiro ao lado de Mitaquassy, Fátima Manadoyá, também demonstrava uma consideração imensa pela nação Nagô. ${ }^{14}$ Esse terreiro é regido pelo vodum nagô Odé.

Além de ter sido o terreiro onde Valmir Pereira foi iniciado, ganhando o nome religioso de Mitaquassy, o Tó Apará serviu de útero ${ }^{15}$ para duas filhas

13 A modalidade Bravum da nação Jeje se deve à referência ao toque rítmico de mesmo nome executado para algumas divindades cultuadas no candomblé de nação Ketu, isto é, as divindades denominadas voduns nagôs (orixás), no Jeje. No Bravum, há primazia e muita estima por essas divindades devido à origem iorubana.

14 Ambos, o dirigente e sua mãe carnal que o ajudava a dirigir a casa, eram pertencentes a uma casa de tradição nagô, onde primeiramente foram iniciados. Quando Valmir Mitaquassy entrou no Candomblé Jeje para nele se iniciar, a casa de candomblé da qual passou a fazer parte foi o Tó Apará, até montar seu próprio terreiro - o Axé Mitaquassy. Na época, a mãe pequena da casa, Sandra Obaganjewí, era casada com a mãe carnal de Valmir Mitaquassy, a saudosa Fátima Manadoyá, e foi a responsável pela iniciação de Valmir na nação Jeje, ganhando ele, então, o nome religioso de Mitaquassy. Sandra Obaganjewí também é mãe de santo de um dos autores deste artigo, sendo Valmir Mitaquassy seu irmão de santo mais velho e seu padrinho de iniciação.

15 Quando pensamos um terreiro como “útero”, estamos nos referindo à sua capacidade original, no conceito de que é, a partir dele, que (re)nascem pessoas para a religião. Para os adeptos, o útero, propriamente dito do terreiro, é sua parte física e espiritualizada mais secreta e sacramental: o quarto onde são realizados os recolhimentos para raspagem da 
de santo dele, Fernanda Gambelejô, mãe da abiyã E. do Axé Mitaquassy, e Y. Iyadolomí. [Além dessas duas] Ao lado de Y. Iyadolomí e da abiyã E. estão o ogã E., e a ekédji W. como crianças que são os sujeitos de pesquisa desta investigação.

Em princípio, foram observadas, nas incursões etnográficas, Y. Iyadolomí e ekédji W., no Tó Apará, antes de integrarem o atual terreiro Axé Mitaquassy. O ogã E. e a abiyã E. já diziam ser filhos de santo de Valmir Mitaquassy, no Tó Apará, mas sem se imporem como filhos de santo oficialmente. O fato de serem crianças não impediu que demonstrassem autonomia no que concerne ao pertencimento religioso, tanto que fizeram a escolha de quem seria o pai de santo deles, oficializando a escolha pela realização do jogo de búzios para saberem quem é o vodum regente de suas cabeças.

Para uma melhor compreensão por parte do leitor, vamos nos referir aqui às crianças que participaram da pesquisa, detalhando, dentro dos limites deste trabalho, suas características.

A primeira criança com quem entramos em contato para a pesquisa e demonstrou sentir-se à vontade foi Y. Iyadolomí. Ela me perguntou do que se tratava e lhe expliquei o que eu estaria fazendo ali. Y. Iyadolomi é neta do pai de santo que dirige o Tó Apará e filha de santo de Valmir Mitaquassy. Ela foi criada pelos dois com a ajuda de Sandra Obaganjewí. Y. Iyadolomi foi raspada para Yemonjá com Iyansã aos 12 anos de idade, com o consentimento de seus pais biológicos, um casal de pele branca que também pertence ao Candomblé, ainda que o pai Alysson Leão se reconheça no candomblé, ele permanece afastado da religião.

Y. Iyadolomí é uma menina de pele branca, cabelos pretos cacheados, quieta, mas eloquente e já está com 14 anos de idade. Suas brincadeiras, à época de seu recolhimento ainda eram "brincar com bonecas", "brincar de comidinhas", "brincar de casinha" e, como acontece com as outras crianças do Candomblé, "brincar de imitar o santo". Mais uma vez podemos perceber aí a relevância da dimensão lúdica sobre o processo de aprendizagem, pois suas brincadeiras remetem a questões referentes ao mundo do terreiro, ainda que não exclusivamente, pois "brincar de comidinhas" também se relaciona ao universo do Candomblé, aos preparativos para os orixás, o que se reverbera na própria aprendizagem sobre o que é ser de candomblé.

cabeça. Esse útero se torna secreto não somente por sua característica física de ser um cômodo da casa mais interno, mas também pelos eventos aos quais serve. De igual modo, podemos pensar um terreiro como útero de outro à medida que de um terreiro podem surgir outros, quer sigam as mesmas tradições litúrgicas, quer rompam com a forma original de onde seus sacerdotes saíram. 
Suas brincadeiras atualmente se restringem a jogo de palavras e escrever. Ela gosta de maçã verde, de purê de batatas, de assistir filmes e de ler sobre sua religião, como ela mesma acha importante dizer e até me pergunta se assisti a um filme ou outro, ou se li algum texto importante que fala de Candomblé, dos santos, e está na internet. Y. Iyadolomi estuda na 6. ${ }^{a}$ série (7. ${ }^{\circ}$ ano) do Ensino Fundamental II em uma escola pública do entorno do terreiro.

Quando se recolheu para raspar o santo, Y. Iyadolomi foi a dofonitinha, de Fernanda Gambelejô, sendo esta a dofona, portanto. Fernanda Gambelejô é mãe da abiyã E., a quem descreverei por último.

Entramos em contato posteriormente com ekédji W. No momento do contato ela ainda não era uma abiyã ekédji, era somente abiyã. Acreditavam que a menina era virante, até que o Odé de Valmir Mitaquassy a levantou como sua segunda ekédji. A primeira ekédji do Odé de Valmir Mitaquassy foi raspada para Oyá com Odé e se chama ekédji Layse Guerewajô.

Ekédji W. é uma menina negra de cabelos compridos pretos e encaracolados. É um tanto tímida e se retrai muito para falar. Ao mesmo tempo em que é calada, não deixa de ser extrovertida quando o assunto é brincar. Suas brincadeiras favoritas são aquelas em que ela pode brincar de realizar suas funções no candomblé, ou seja, ser ekédji de algum santo de "faz de contas" com as outras crianças. Ekédji W. estuda na $3^{\mathrm{a}}$ série (4\% ano) do Ensino Fundamental I em uma escola privada distante de seu bairro. Na escola, essa menina gosta de estudar Matemática porque gosta de fazer contas e, nessa matéria, sempre tem melhor desempenho, apesar de ser considerada como aluna exemplar onde estuda e tira boas notas nas outras disciplinas.

Os pais de ekédji W. são um casal de negros e são membros do Tó Apará. A mãe de ekédji W. é a vodunsi dofonitinha Elaine Sabaomilê e o pai foi raspado no mês de novembro de 2014 como axogum da Oxum Yeyê Apará de Marcos Aparalomí. Ekédji W. é uma menina sensível de apenas 10 anos de idade. Ela já sabe que vai raspar a cabeça para o santo Jagum, um tipo de Obaluayê que vem acompanhado de Oxaguiã e Oxum no juntó. ${ }^{16}$

A terceira criança é o ogã E. que devido à sua timidez foi muito difícil trazê-lo à pesquisa. Sempre foi possível ver ogã E. brincando com as outras crianças, desde brincadeiras com bola, até as brincadeiras de "imitar o santo" ou tocar para o santo. Nas horas dos rituais de obrigações, ou nas festas, o garoto se retraía e não tocava nem cantava o que sabia.

\footnotetext{
16 Juntó é o termo nagô de identificação dos santos que acompanham, em segundo ou terceiro lugar, o orixá, isto é, o santo principal. Juntó é o santo que acompanha o primeiro santo em uma cabeça, seja de um religioso do Candomblé, ou da Umbanda.
} 
Ogã E. é um ogã não raspado ainda, isto quer dizer que ele é somente um ogã suspenso. Ele já tem 14 anos de idade e foi levantado aos 13 anos pelo Odé de Valmir Mitaquassy no Tó Apará, assim como sua irmã ekédji Layse Guerewajô. É um menino magrinho, negro, ainda chupa dedos e não dispensa comida, especialmente se for alguma comida diferente da que costuma comer no dia a dia, o típico arroz com feijão e carne.

Ao final de cada obrigação ou festa, ogã E. faz questão de conversar sobre os santos que viraram nos filhos de santo e o que aconteceu, o que achou bonito e pergunta o porquê das coisas. Quando Valmir Mitaquassy jogou os búzios para saber de qual santo ogã E. é filho, à primeira vez a resposta foi que ele é filho de Odé. Na segunda vez, o jogo mostrou que ele é filho de Ogum. E tudo isso ficou ainda incerto para o menino. Mesmo assim ele se considera uma criança do santo, e apenas tem a certeza que só saberá de qual santo é filho nos momentos próximos de raspar a cabeça.

Depois de certo tempo de vivência no Tó Apará e no Axé Mitaquassy, og ã E. se desinibiu e passou a tocar, cantar e participar de maneira mais ativa nas obrigações e festas. Ao mesmo tempo em que isso ia acontecendo, ele ia reparando na minha presença com suas duas irmãs de santo e foi se chegando mais, o que me leva a crer que sejam indícios de um amadurecimento sem deixar de ser criança.

A é a filha de dofona Fernanda Gambelejô, a abiyã E. Essa menina já sabe que é filha de Yemanjá com Odé. É uma menina tímida e calada, mas quando perguntei a ela de que santo ela era filha, prontamente ela começou a responder o que tinha se passado: "eu sou filha de Yemanjá com Odé. O Pai Valmir jogou pra mim e deu esse jogo". Quando comecei a perguntar a ela se ela gostava do Candomblé, ela começou a me responder que sim e a falar das danças, da roda, das músicas e que um dia vai ser raspada. Um dos desenhos que essa menina fez logo após uma festa que aconteceu no Tó Apará foi de uma jovem vestida com roupas de candomblé. Perguntei a ela o que era aquele desenho, e ela me respondeu que era sua irmã de santo Maria Helena de Yemonjá, outra abiyã do Axé Mitaquassy.

Evidencia-se com o desenho de abiyã E. que a família de santo para essa menina também é algo que está representado pela fraternidade na subjetividade dela sobre o Candomblé. Abiyã E. é uma menina de pele branca e cabelos longos cacheados. Ela tem 7 anos de idade, e ainda está na alfabetização numa escola particular no bairro onde mora com sua mãe e seus irmãos. Um de seus irmãos ainda é "criança de braço", ao passo que o outro diz abertamente que não gosta da "macumba", com seu tio e sua avó. 
Outras crianças também foram observadas nas festas e obrigações que acontecem no Tó Apará, ${ }^{17}$ pois frequentam o terreiro. Algumas dessas crianças podem ser classificadas como crianças de Candomblé, mas não oficialmente, porque não assumiram o compromisso de integrar o grupo religioso. No entanto, elas se afirmam como tal, como filhas e filhos de algum santo, assistem e até participam, mesmo que como espectadores e espectadoras, de festas e rituais de obrigação. Uma delas é filha da mãe pequena da casa, Sandra Obaganjewí, que mora com ela no terreiro. Essa criança de 8 anos de idade, que aqui iremos chamar de Pequena de Iyansãa, se diz filha de Iyansã com Ogum e que o pai de santo dela é o Valmir Mitaquassy.

Quando foi questionado à mãe de Pequena de Iyansã sobre sua filha ser uma criança de Candomblé por afirmar tais pertencimentos e morar com ela no terreiro, Sandra Obaganjewí respondeu que sim, que ela não tem como fugir, mas que prefere que sua filha não firme qualquer compromisso até ficar maior, e decidir o que realmente quer para a sua vida, já que ela é uma criança rebelde, que não se sujeitaria a baixar a sua cabeça para algum pai de santo.

A razão apresentada por Sandra Obaganjewí para sua filha, Pequena de Iyansã, não fazer parte oficialmente, até então, da religião é que certas atividades executadas pelos filhos e filhas de santo em uma casa de candomblé são extremamente exaustivas e ela não gostaria de ver sua filha "explorada" por algum sacerdote como ela disse ver por aí. Essas atividades são, em sua maioria, atividades domésticas relacionadas à limpeza do terreiro.

Na concepção de Sandra Obaganjewí, a rebeldia de sua filha ao se negar a executar algumas dessas atividades causaria atritos entre ela e a filha com o pai de santo. Esses permanecem sendo os motivos para não incluir Pequena de Iyansã como uma pesquisanda oficial dessa etnografia. No entanto, é impossível desviar a vista dela, sendo ela uma criança observada tão presente em todas as atividades do terreiro.

O que se pode perceber, a partir desse fato brevemente narrado, é que a agência infantil se coloca ante a agência do adulto, não sendo possível uma simples imposição dos pais sobre os filhos, pois a produção de sentidos para as práticas no Candomblé passam, necessariamente, por um contínuo

17 As obrigações e festas no Axé Mitaquassy foram temporariamente suspensas devido à morte da mãe de santo desse terreiro, Fátima Manadoyá. As obrigações que se executariam nele estão sendo feitas todas no Tó Apará. Isso confirma mais ainda os laços que ambas as casas mantêm, conflitando-se, às vezes, por problemas pessoais entre os dirigentes das duas casas, mas não deixando de serem executadas pelo motivo da força maior ser o que se faz para o santo. 
processo de negociação de sentidos, e as características próprias de cada criança devem ser respeitadas no processo de construção de seu lugar no mundo, de seu lugar no terreiro.

Quando dizemos "negociação de sentidos", estamos afirmando que a hierarquia existe, mas que os aprendizados acontecem de modo dinâmico e circular, apesar de uma apresentação mais visivelmente vertical. No entanto, é pela dinamicidade e circularidade existentes no âmbito da educação, do ensino e da aprendizagem, em constituição dos sujeitos, que eles perfazem os sentidos do que é feito por meio de suas próprias práticas consonantes às dos outros. Equivale dizer que os sujeitos não se constituem sozinhos, nem constituem seus saberes da mesma maneira, mas perlaboram tudo, tomando como parâmetros os outros e os sentidos que possam existir para que se negociem quais fariam mais ou menos sentido individual e coletivamente.

Outra criança, que aqui denominamos de Pequena de $\operatorname{Ogod\hat {o}},{ }^{18}$ participa ocasionalmente de algumas atividades do terreiro. Em algumas horas livres, ela está transitando no terreiro, brincando com Y. Iyadolomí e, em dias de obrigação, quando todas as crianças ficam juntas, é possível vê-la em meio a elas nas brincadeiras mais comuns. As outras crianças de Candomblé, assim como Pequena de Ogodô e seu irmão ogã E. fazem parte da vizinhança do terreiro, ou são filhos carnais dos filhos de santo do Tó Apará.

A mãe e o padrasto de ogã E. e Pequena de Ogodô não fazem parte da religião, consideram-se católicos, mas não congregam, nem comungam da ritualística católica de ir à missa e se confessar. Para a mãe de ogã E. e Pequena de Ogodô, Dona Mônica, no Candomblé os filhos estão seguros sendo orientados. Essas duas crianças são irmãos de uma jovem que chegou ao terreiro aos 12 anos de idade, ekédji Layse Guerewajô. Quando Layse chegou ao terreiro Tó Apará ainda criança, foi acolhida como filha de santo de Valmir Mitaquassy e passava a maior parte de seu tempo no terreiro do que em casa.

Após começar a dançar na roda desse candomblé e realizar algumas obrigações menos complexas que um borí ou uma raspagem da cabeça, Layse foi matriculada em uma escola estadual do entorno do terreiro por Sandra Obaganjewi e Valmir Mitaquassy, no turno matutino. Dessa forma, restavam a Layse as tardes livres para os deveres de casa e os afazeres no terreiro. Esses dois sacerdotes apadrinharam-se da menina não só como tutela informal,

18 Ogodô é a forma como é conhecido o vodum nagô Xangô (orixá Xangô) quando vem acompanhado por Oxum na cabeça de alguém. No caso, essa criança foi identificada pelo pai de santo Marcos Aparalomí como filha de Xangố com Oxum. 
mas como padrinhos na religião católica por meio da cerimônia de batismo dela, que se deu aos seus 12 anos de idade ainda.

A jovem ekédji Layse Guerewajô chegou ao terreiro da mesma forma que seu irmão ogã E. e sua irmã Pequena de Ogodô. Morar na vizinhança do terreiro não impede que as crianças transitem pela frente dele e se encantem com suas formas, cores, objetos à mostra na frente da casa, assentamentos visíveis publicamente, além de festas e obrigações das quais podem ser vistas as danças e a movimentação e ouvidos os sons das músicas e do toque dos atabaques. Todas as outras crianças que estavam no terreiro, sem que seus pais tenham ligações com essa religião, chegaram nele vindas da vizinhança, encantadas com tudo o que já foi citado.

Assim como manifesto por Dona Mônica, Dona Madalena, numa das conversas informais na porta do terreiro Tó Apará, entre uma atividade e outra das obrigações de Babá Jorge Patulasí, afirmou que sente que suas filhas estão seguras e bem cuidadas quando estão no terreiro. Dona Madalena é mãe de vários filhos, duas de suas filhas vão ao terreiro com muita frequência nas festas.

Dona Madalena afirmou que não tem a mínima vontade de participar dessa religião, mas que suas filhas têm vontade e até pediram a ela para dançar na roda das festas. "Eu só não deixo as minhas filha nessa religião porque gasta muito com roupa e comida nas festas. Nem elas, nem eu tem esse dinheiro. Mas eu acho até melhor elas no terreiro porque assim eu sei que elas não estão na rua e estão sendo bem cuidadas. Pelo menos não dão trabalho a mim", contou Dona Madalena. Isso que Dona Madalena falou expressa um pouco os sentimentos dos pais que não pertencem à religião e deixam seus filhos frequentarem o terreiro.

Essas são as crianças que encontramos nos dois terreiros: aquelas crianças que são filhas de pais religiosos do terreiro de Candomblé, aquelas que vão ao terreiro com o consentimento dos pais que não pertencem à religião, e Pequena de Iyansã, que mora no terreiro, diz-se religiosa, mas não tem o consentimento da mãe.

O que percebemos é que, para além desse processo de invisibilização das crianças de candomblé, é importante destacar o quão heterogênea é a realidade delas, o que implica também na atribuição de sentidos diversos para o que é aprendido. Para algumas crianças, o Candomblé é tido como religião por excelência, de modo que o aprendizado deve ser visto como uma etapa rumo a uma iniciação futura - o que não é necessariamente vislumbrado por todas as demais crianças. 


\section{Mas, afinal, o que é ser uma criança de/no candomblé?}

Para tentarmos responder à pergunta que lançamos nesse subtópico, vamos primeiramente aos casos de Y. Iyadolomí e ogã E. É importante deixarmos claro que partimos de uma compreensão plural de infâncias, entendendo que há inúmeras possibilidades de ser criança (COHN, 2005; GOMES, 2008), havendo, portanto, características próprias da infância no Candomblé. O fio que podemos assumir como condutor aqui pode ser a seguinte indagação: Por que Y. Iyadolomí e ogã E. ainda são consideradas crianças mesmo com 14 anos de idade?

Y. Iyadolomi é neta do pai de santo Marcos Aparalomí. Sua mãe, Patrícia Ominaguesí, é uma das mães de santo do Axé Apará, que foi casada com Alysson Leão, filho carnal ${ }^{19}$ de Aparalomí. Desde muito nova, ainda bebê, Y. Iyadolomi foi cuidada e criada na casa de Marcos Aparalomí, a pedido dele, por Sandra Obaganjewí. Marcos Aparalomí é muito apegado com crianças pequenas e, mesmo quando elas crescem e se tornam adultas, para ele ainda são todas suas crianças. O que sucedeu a Y. Iyadolomí é quase o mesmo que sucede a Pequena de Iyansã. Y. Iyadolomí foi criada participando de tudo dentro da religião, assistindo a rituais abertos e fechados desde muito nova, entretanto, sua participação nos afazeres mais "pesados", relativos à limpeza do salão e dos objetos, era impedida por ser uma criança pequena. O que era requerido por parte de seu avô era sua presença assistindo a tudo o que se fazia, o que se relaciona à possibilidade de encararmos a participação religiosa como um processo mais amplo de aprendizagem. Nesse sentido, socialização e educação tornam-se sinônimos.

Raspada desde os 12 anos de idade, Y. Iyadolomí agora tem 14 anos de idade, e mesmo hoje é mais requerido que ela estude e tenha tempo livre se dedicando a outras atividades que não sejam a parte "pesada" de limpeza do salão ou afazeres domésticos do terreiro. Os membros da casa ainda enxergam Y. Iyadolomí como uma menina que não deve se cansar carregando pesados baldes de água para lavar o salão, esfregando o chão respingado de sangue dos sacrifícios, lavando caldeirões e incontáveis pratos usados nos "comes e bebes" do final das festas etc. Percebe-se que Y. Iyadolomi tem 14 anos de idade, porém ainda é criança, o que se deve tanto a suas atitudes e quanto ao fato de não se desvencilhar do domínio e do olhar dos adultos, especialmente de seu avô, de tal modo que ela é considerada uma criança maior.

19 Esta é uma categoria nativa que é utilizada para distinguir os vínculos biológicos daqueles que se constituem no nível religioso, referente à família de santo. 
A situação de Y. Iyadolomí se diferencia um pouco quando ela está no Axé Mitaquassy e tem de fazer todas as atividades que lhes são atribuídas. Ao ser indagada sobre o que ela acha que é, se adulta ou criança, ela diz que acha que ainda é uma criança: "eu acho que ainda sou criança porque eu faço coisas que é pra criança fazer. Mas o pessoal diz que eu sou pré-adolescente. Mas eu não acho isso, só se for pra eles. Porque aqui eu ainda sou criança, só não faço tudo de criança porque eu já parei muito de brincar". Mesmo dizendo que ela parou muito de brincar, ainda é possível encontrar Y. Iyadolomí em meio às outras crianças brincando de "pegar o santo".

No caso de ogã E., muitas atividades que lhes são requeridas dizem respeito à sua função como ogã tanto da casa de seu pai de santo, quanto no Tó Apará, para onde ele foi levantado com esse cargo pelo Odé de meu irmão de santo Valmir Mitaquassy. Dos afazeres domésticos e limpeza do salão e dos objetos ele é mais dispensado, entretanto, até das atividades inerentes à sua função ele prefere escapar para brincar com as outras crianças, seus irmãos e filhos de vizinhos. Para ogã E., é mais sério e importante realizar alguma atividade na brincadeira do que nos momentos de seriedade dos adultos. E encontrarmos ogã E. tocando atabaque ao brincar com outras crianças no terreiro e se negando a tocar atabaque durante as festas, porém durante as obrigações isso muda, e ogã E. pega os aguidavis para tocar atabaque.

Não significa que a essas crianças não seja cobrada uma postura de seriedade adulta, ao contrário, já que há um intenso processo de aprendizagem no terreiro que é pensado principalmente como uma forma de "transmissão cultural" dos adultos para as crianças, pois como afirmou Valmir Mitaquassy: “[...] o terreiro também é uma escola, aqui é como uma escola, tem tempo para aprender tudo e o que se tem para fazer cada um vai fazer", o que inclui desde os afazeres domésticos, o cuidado com a mobília e objetos do terreiro, aos religiosos.

Valmir Mitaquassy ainda colocou que: "[...] eu ensino tudo, tudo eu ensino. Só não vou ensinar o que não pode aprender, porque tem o tempo certo. Mas de tudo eu ensino", nesse caso específico ele se referia a suas filhas de santo Y. Iyadolomi e ekédji W., que é a mais nova ekédji de seu santo, pois a primeira é ekédji Layse Guerewajô, já raspada.

O que podemos notar é que, na percepção dos adultos, as crianças são seres em transição, e que para que essa transição se faça completa é necessário que um adulto guie a aprendizagem das crianças, sem embargo. 
Como já indicamos, há um intenso processo de aprendizagem horizontalizado entre as crianças.

Ainda a respeito dessa percepção das crianças como seres em transição, podemos indicar que em alguns momentos isso fica ainda mais evidente. Por exemplo, na obrigação de Babá Jorge Patulasí, na noite do dia 13 agosto de 2014, estavam presentes as crianças filhas de santo de Valmir Mitaquassy e o erê de Valmir Mitaquassy. Esse erê se chama Lírio dos Vales e carinhosamente o chamam só de Lírio. É um menino muito risonho, brincalhão e não fala com uma expressão vocal bem desenvolvida. Enquanto as outras crianças cochichavam entre si ou sorriam de alguma coisa que achavam engraçada, até mesmo brincando com o Lírio, era cobrada a elas atenção, seriedade e dedicação com uma frase costumeira dos rituais de candomblé vinda da parte de Marcos Aparalomí “isso aqui é coisa séria, viu?!” No entanto, ao Lírio não era cobrada essa postura. Lírio podia brincar e sorrir como bem entendesse, até deitava e rolava no meio do salão enquanto se executava a obrigação para as divindades.

O fato narrado pode ser explicado da seguinte forma: de Lírio não se espera algum crescimento ou desenvolvimento senão aquilo que lhe é próprio fazer - brincar e transmitir diretamente as mensagens do santo. Essa é a inocência e infantilidade encontrada no erê que não vai se tornar um adulto. Das crianças, é esperado que cresçam e amadureçam de modo adulto, para continuarem desenvolvendo as atividades do Candomblé.

Ainda nessa obrigação, quando a Yemonjá da Dofonitinha Lúcia de Yemonjá virava por causa de algum fundamento realizado na obrigação, do qual já se esperava que ela virasse, Lírio pegava a vareta de bambu com a qual estava brincando e tocava na Yemonjá para que ela desvirasse da cabeça de Dofonitinha. Isso porque na realização de um fundamento, como o corte do obí, o santo muito recentemente raspado é obrigado a virar na cabeça do vodunsi como confirmação da realização do fundamento. Porém, o santo não é obrigado a ficar virado, devendo ser desvirado. E para desvirar a Yemonjá de Dofonitinha Lúcia, Lírio usava a vareta, tocando nela e sorrindo.

Durante as obrigações, ekédji W. que até sorri, brinca e cochicha com os demais, brinca especialmente nos intervalos das obrigações, mas também quando vai desvirar um santo. Ekédji W., de apenas 10 anos de idade, realiza as obrigações de seu cargo com a responsabilidade que ele demanda, sem que com isso sejam apagados os traços de ludicidades presentes em seu fazer.

Para ogã E., ele também é uma criança, mesmo com 14 anos de idade, não dependendo só da visão dos adultos sobre ele. Nos momentos livres após 
a realização das obrigações, quando muitos dos filhos de santo dormem no salão para retornarem às suas casas no outro dia, realizamos uma conversa com ele acerca da sua participação nos rituais das obrigações e ele me disse que ainda é uma criança, porque tem coisa que não é para ele fazer. Com esse mesmo pensamento, ekédji W. manifesta seu senso de infantilidade, ao afirmar que nem faz tudo porque nem tudo ela pode fazer.

Em uma entrevista com ekédji W., algumas horas antes da realização da festa de Mãe Tonha de Oyá, uma mãe de santo nagô que deu obrigação pelas mãos de Valmir Mitaquassy no Tó Apará, ekédji W. disse: "[...] eu ajudo nas obrigações, eu danço aqui também, várias coisas", referindo-se às suas atividades no terreiro e que ela estava "[...] ajudando como uma pessoa normal, mas só que menor" porque ela fazia "[...] quase tudo". Esse quase tudo nas palavras dela eram as "[...] coisas que dá pra fazer porque eu sou pequena ainda".

Nessa conversa com ekédji W., ficou muito latente a recorrência à palavra "normal" em todo o seu discurso, na intenção de apresentar o seu senso de normalidade a respeito de sua condição como criança e de sua participação religiosa não ser uma abjeção social. Ainda nas palavras dela: "[...] normal pra mim é levar uma vida de criança como eu sou". Para ela, ser uma criança e normal é "[...] brincar, estudar, ser criança é levar uma vida divertida", e que nessa parte da diversão é que se aproximam dos erês.

\section{O terreiro como espaço de aprendizagem}

Além do que foi exposto até aqui, temos que considerar ainda que no conjunto de atividades rituais e afazeres domésticos desse terreiro as crianças ajudam e até desenvolvem sozinhas algumas ações, pois a elas é confiada a capacidade de execução, tendo em vista que passam por um processo de aprendizagem para desempenhar tais funções. Aprendem palavras, frases, cânticos e rezas em idiomas como o iorubá, o fongbé, o quimbundo etc., o que pode ser compreendido como parte de uma resistência cultural (PRANDI, 2004), em especial por se tratarem de crianças às quais esse legado cultural é confiado.

As crianças também aprendem o uso ritual de vegetais (ervas, grãos e raízes), minerais (sal, carvão, pedras e águas) e animais que integram a base alimentar permitida, tabu e destinada às divindades. No que compete a todos esses saberes, o espaço escolar simplesmente olvida que sua importância seja rica na formação intelectual das crianças (SANTOS, 2008). Entram também no leque de conhecimentos aprendidos no terreiro as atividades de cozimento dos alimentos de origem animal e de origem vegetal, que se ligam tanto ao mundo 
sagrado, quanto ao profano, já que passam a ser utilizados dentro do terreiro na ritualística sacrificial que essas crianças participam, isto é, nos rituais de corte de animais oferecidos à alimentação das divindades, com a comunidade participante dos ritos internos e públicos (as festas), e fora dele para a vida.

Os pratos da culinária afro-brasileira, veementemente simbólicos da força de cada divindade, oferecidos durante essas festas, retratam uma forma de comunhão entre humanos e divindades, ou seja, como através do alimento o sujeito se relaciona com o sagrado, reconhecendo-o como fonte de força e energia, o que vão chamar de axé, de tal modo que a fé no candomblé pode ser compreendida pelas relações desencadeadas com a festa, a dança e a comida (MOTTA, 1982; 1995), manifestas no corpo, ademais a comida é, por excelência, um espaço de aprendizagem no Candomblé (RABELO, SANTOS, 2011). Fonseca (1997) destaca a posição central das músicas e das danças nas festas de candomblé, ao que acrescento as rezas, enfatizando a necessidade do entusiasmo ao cantar, o que não faz desmerecer a posição do aprendizado de tais músicas e danças. Nesse sentido, não podemos olvidar que:

Aprender leva tempo. Não só porque juntar porções de conhecimento é tarefa que não se resolve segundo uma linha de continuidade previamente estabelecida, mas ao sabor de oportunidades que podem ou não se oferecer, mas também porque se exige do iaô que viva intensamente o lugar que é lhe reservado no terreiro: e esse é o lugar de alguém que está na base de uma hierarquia mais ou menos rígida. Para aprender, iniciantes devem primeiro obedecer. Ou melhor, obedecer é condição para que o aprendizado seja deslanchado e essa condição também precisa aprendida (RABELO, 2015, p. 237).

Todavia, parece-nos que no caso das crianças o aprendizado toma determinadas características mais singulares, uma vez que ele ocorre sobretudo por meio da ludicidade expressa pelas brincadeiras das crianças, não significa dizer que elas também não vivenciem outros processos de aprendizagem, nos quais se faz sentir toda a força da hierarquia do terreiro, e toda a dificuldade existente em captar claramente os momentos específicos de aprendizagem, algo que Goldman (2005) indicou que se assemelha a uma coleta de folhas. Mais ainda, há que se considerar que, no que tange às brincadeiras, não há distinção entre o que para elas seja sério e o que possa ser retraduzido como brincadeira, da qual, na cultura própria das crianças, elas necessitem para aprender (SARMENTO, 2004). Amâncio (2016, p. 31) em seu trabalho indica que compreende o brincar e a brincadeira "[...] como fundamental e 
constitutivo do ser humano, enquanto um ato de criação, mas também, uma forma de resistência de que as crianças se utilizam para transgredir as regras estabelecidas e instituir novas regras". Isso é especialmente evidente no caso das crianças pesquisadas, pois a possibilidade de vivenciar determinadas experiências sociais, ultrapassando as fronteiras impostas pela hierarquia do terreiro, só é possível através do acionamento das brincadeiras, que funcionam como uma forma de participação ativa na vida desse espaço, dentro do que Corsaro (2011) denomina de "reprodução interpretativa".

Falcão (2010, p. 64-65) indica que em sua pesquisa uma criança relata a seriedade exercida em sua própria cultura de criança: “[...] para Camilo, as brincadeiras de Candomblé são uma forma de assumir a religião de sua família, a qual nem ele nem seus primos parecem ter vergonha", sendo assim, a brincadeira deve ser entendida tanto como um processo de aprendizagem, quanto como uma prática para a afirmação de sua própria identidade religiosa.

Não negamos com isso que os adultos brinquem, inclusive no espaço ritual, afinal a dimensão lúdica é constitutiva das práticas sociais entre os seres humanos, entretanto, o lugar que essa prática ocupa no universo infantil é substancialmente diferente. A brincadeira é encarada com seriedade pelas crianças, por assim dizer, e por meio delas ocorre a elaboração de sua própria cultura, a reelaboração da cultura dos adultos, e a construção de sua forma de estar no mundo. É brincando também que se aprende uma das questões mais fundamentais do terreiro, que diz respeito às hierarquias existentes, que se centram mais no tempo de iniciação de cada membro do que em sua idade cronológica.

Pires (2010) nos dá pistas de como podemos pensar a aprendizagem na face cultural ao trazer que aprender é contínuo para o adulto e para a criança, a qual também ensina, havendo outras maneiras de se realizar o processo educativo que não seja aquele que põe a criança como sujeito passivo. Basta notar que sua presença, suas reações e seus estímulos agem ativamente a qualquer atividade educativa, inclusive interferindo no modo como se dará ela. O que torna isso ainda mais proeminente é a oralidade característica dos ensinamentos do Candomblé, pois ao passo que a cultura da escrita é típica do universo adulto, a cultura oral é mais "democrática", pois está presente no mundo dos adultos e das crianças.

O terreiro deve ser pensado, portanto, como um locus de circulação de saberes, o que ocorre em múltiplas direções, sendo assim, não negamos com isso que haja um processo de aprendizagem dos adultos para as crian- 
ças, pois de fato aqueles tentam direcionar a aprendizagem destas, inclusive repreendendo as brincadeiras consideradas inapropriadas para o momento, levando-as para o terreiro, inserindo-as nas atividades rituais, mas chamamos a atenção que esse não é o único sentido em que o saber circula, pois dentro daquilo que Corsaro (2011) denominou de "Cultura de Pares" há uma intensa aprendizagem, as crianças também aprendem entre elas. Em sua definição, Cultura de Pares seria:

[...] um conjunto estável de atividades ou rotinas, artefatos, valores e preocupações que as produzem e compartilham em interação com outras crianças. Essa visão da cultura de pares está em conformidade com a reprodução interpretativa, que sublinha as ações coletivas da criança, valores partilhados e o lugar e participação infantis na produção cultural (CORSARO, 2011, p. 151).

Nesse ponto, concordamos com o que é posto por Cohn (2005), ao indicar que a diferença do saber da criança com relação ao saber do adulto não se dá em termos quantitativos, mas sim qualitativos, pois a criança não sabe menos que o adulto, mas ela sabe algo diferente deste.

Quando um grupo de crianças se junta e brinca de "pegar santo", onde cada uma ocupa uma posição do ritual, e o corpo se apresenta como uma importante ferramenta, uma vez que é por meio dele que as crianças brincam, movimentam as mãos de acordo com o gestual do orixá, não se trata apenas de um mimetismo com relação ao universo adulto, ainda que elementos deste sejam mobilizados, mas sim da produção de uma forma de aprendizagem, que se circunscreve na própria "gramática corporal” existente nas religiões afro-brasileiras (PÓLVORA, 1995).

$\mathrm{Na}$ noite anterior ao dia da festa de saída de Dofono Otolojêe, no Tó Apará, uma sexta-feira, dia 18 de julho de 2014, estavam Pequena de Ogodô e Pequena de Iyansã brincando de dançar para o santo que era interpretado por outra criança, enquanto ekédji W. dançava com esse santo de "faz de conta", desempenhando sua função de ekédji, e ogã E. tocava o atabaque para o santo de "faz de conta" dançar, desempenhando na brincadeira também a sua função de ogã. Nesse cenário, outras crianças da vizinhança faziam o papel de vodunsis cantando as músicas sagradas das divindades que aprenderam e batendo palmas.

Nesse processo, que por vezes pode ser malvisto pelos adultos, pois as crianças brincam com "coisas sérias", há a elaboração de outras formas de aprender que escapam do direcionamento que os adultos podem exercer, 
e que emergem como reflexo das sociabilidades vivenciadas no terreiro e no seu entorno, uma vez que envolvem também crianças que, mesmo não sendo iniciadas no candomblé, também participam da brincadeira.

A brincadeira experimentada principalmente, ainda que não exclusivamente, entre os pares que, em nossa interpretação, é a chave para compreendermos os processos de aprendizagem vivenciados. É por meio delas que as crianças buscam entender o ritual, realizando assimilação que só se efetiva na prática, o que é operacionalizado por meio do chamado "faz-de-conta" (CORSARO, 2002).

A cultura de pares à qual faz referência Corsaro (2011) propicia o surgimento de uma interação que se dá fortemente assentada nas atividades do lazer, tendo como produto experiências enriquecedoras em termos culturais para as crianças, que brincam juntas, e nisso também lidam com a própria alteridade.

\section{Considerações finais}

O amplo material etnográfico que foi produzido no decorrer da pesquisa, aqui resumidamente apresentado, nos possibilitou perceber que não há uma única forma de aprender, tampouco uma única concepção de infância, tendo em vista que, ao nos remetermos à realidade do Candomblé, amplamente assentado nos processos não formais de aprendizagem, ganha espaço a dimensão lúdica como elemento central na prática educativa das crianças do terreiro.

As crianças de candomblé, ainda que bastante invisibilizadas pela literatura que aborda as religiões afro-brasileiras, são sujeitos ativos, agenciadores e produtores de cultura. O agenciamento dos adultos ainda que evidente - tendo em vista que há uma preocupação por parte destes em perceber o momento "certo" para pertencer ou não à religião, além de produzirem algumas adaptações dos rituais à realidade infantil (CAPUTO, 2012; BERGO, 2011) - não direciona completamente os processos de aprendizagem, nem mesmo os comportamentos das crianças no espaço dos terreiros, a brincadeira que é compreendida como uma oposição às "coisas sérias do santo" não se opõe na agência infantil.

Também é importante ressaltar a relevância que a Cultura de Pares assume no terreiro, pois ao brincarem de "imitar o santo", tocando os atabaques, por vezes simples baldes, reproduzindo o gestual dos orixás quando incorporados, replicando a hierarquia do terreiro, sem que com isso haja qualquer intervenção dos adultos, eles não estão apenas brincando, estão dando conti- 
nuidade ao Axé, aprendendo com ele também, e aprendendo principalmente entre as próprias crianças, o que se dá de forma gradual em articulação ao que é continuamente observado (OLIVEIRA, ALMIRANTE, 2014).

Esses sujeitos foram considerados crianças a partir da construção social existente no terreiro, tendo em vista que a concepção de infância existente nele se dá a partir do lugar ocupado nas funções ritualísticas e nos afazeres domésticos, havendo uma gradação do mundo do adulto para o da criança, ainda que estas possam ocupar um lugar na hierarquia da casa, por vezes mais alta que alguns adultos que ainda não foram iniciados. Ainda com relação a essas concepções de infância, é importante perceber que há uma hierarquia infantil também, que se relaciona ao processo de iniciação das crianças, bem como, às funções que ocupam na casa.

Há, também, nas casas de Candomblé que contam com a participação de crianças, dois códigos, um do santo e outro cronológico-biológico. No primeiro, haveria uma ruptura à lógica exterior do terreiro, predominando a senioridade em termos de tempo de iniciação; no segundo haveria uma continuidade, na qual os mais velhos teriam um maior prestígio que os mais jovens, portanto as crianças estariam na base dessa hierarquia. Tal como Maggie (2001) coloca em sua pesquisa a partir de uma casa de umbanda, num terreiro não há apenas um código social que rege as relações desenvolvidas nesse espaço, de tal modo que os diversos códigos existentes são mobilizados pelos agentes visando determinadas finalidades, o que ocorre também com as crianças que mobilizam as possibilidades e interdições que são postas à sua condição de "não adulto".

Por fim, ainda que não tenha sido o foco deste trabalho, é importante ressaltarmos a necessidade de pensar os diálogos possíveis entre as diversas formas de aprender, sendo essa uma das principais contribuições que podem se originar a partir do campo da Antropologia da Criança (TASSINARI, 2011), bem como as múltiplas concepções de infância e a escola.

Se, como indica Sarmento (2011), no espaço escolar a criança desaparece ante a escola, restando-lhe apenas o aluno, destituído de toda a sua bagagem cultural, no caso das crianças de Candomblé, esse processo é ainda mais evidente, tendo em vista a forma como a intolerância religiosa e o racismo se articulam no espaço escolar (OLIVEIRA, 2014).

Os dados etnográficos apresentados buscam demonstrar como os processos de aprendizagem das crianças podem ser articulados de modo bastante complexos, e mais que isso, almejamos destacar o papel ativo das crianças 
na vida social do terreiro, indicando também a ludicidade como uma forma de subversão das hierarquias e de criação.

\section{Referências}

AMÂNCIO, Hélder Pires. Da casa à escola e vice-versa: experiências de início escolar de crianças em Maputo, 2016. Dissertação (Mestrado em Antropologia Social) - PPGAS, Universidade Federal de Santa Catarina, Florianópolis, 2016.

BASTIDE, Roger. O Candomblé da Bahia: rito nagô. São Paulo: Companhia das Letras, 2001.

BERGO, Renata. Quando o Santo Chama: o terreiro de umbanda como contexto de aprendizagem na prática, 2011. Tese (Doutorado em Educação) - PPGE, Universidade Federal de Minas Gerais, Belo Horizonte, 2011.

CAPUTO, Stela Guedes. Educação em terreiros - e como a escola se relaciona com crianças de candomblé. Rio de Janeiro: Pallas, 2012.

COHN, Clarice. Antropologia da Criança. Rio de Janeiro: Jorge Zahar Editor, 2005.

CORSARO, William A. Sociologia da Infância. Porto Alegre: Artmed, 2011.

. A reprodução interpretativa no brincar ao "faz-de-conta" das crianças. Educação, Sociedades \& Culturas, s/v, no ${ }^{\circ}$ 17, p. 113-134, 2002.

FALCÃO, Christiane Rocha. "Ele já nasceu feito": o lugar da criança no Candomblé, 2010. Dissertação (Mestrado em Antropologia) - PPGA, Universidade Federal de Pernambuco, Recife, 2010.

FONSECA, Eduardo Aquino. O significado das festas nas religiões afro-brasileiras. Cadernos de Estudos Sociais, v. 13, n. 2, jul./dez, 1997.

GOLDMAN, Marcio. Formas do saber e modos do ser: multiplicidade e ontologia no candomblé. Religião e Sociedade, v. 25, n. 2, p. 102-120, 2005.

GOMES, Ana Maria Rabelo. Outras crianças, outras infâncias? In: GOUVEA, Maria Cristina Soares; SARMENTO, Manuel (Org.). Estudos da Infância - Educação e práticas sociais. Petrópolis: Vozes, 2008, p. 82-96.

HIRSCHFELD, Lawrence. Why don't Anthropologists like Children? American Anthropologist, v. 104, n. 2, p. 611-627, 2002.

MAGGIE, Yvonne. Guerra de Orixá: um estudo de ritual e conflito. Rio de Janeiro: Jorge Zahar Ed, 2001.

MOTTA, Roberto. Sacrifício, mesa, festa e transe na religião afro-brasileira. Horizontes Antropológicos, v. 2, n. 3, p. 31-38, 1995.

Comida, família, dança e transe: sugestões para o estudo do xangô. Revista de Antro-

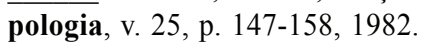

OLIVEIRA, Amurabi. A Vez das Religiões Afro-Brasileiras no Ensino Religioso? as possibilidades e limites abertos pela lei $\mathrm{n}^{\circ}$. 10.639/03. Numen: revista de estudos e pesquisa da religião, $\mathrm{v}$. 17, n. 1, p. 171-188, 2014. 
OLIVEIRA, Amurabi; ALMIRANTE, Kleverton Arthur. Aprendendo com o Axé: processos educativos no terreiro e o que as crianças pensam sobre ele e a escola. Ilha - Revista de Antropologia, v. 16, n. 1, p. 139-174, 2014.

OLIVEIRA, Amurabi; ALMIRANTE, Kleverton A.; SANTOS, Fernanda N. O Xangô na Sala de Aula: dilemas da identidade religiosa afro-brasileira em Alagoas. Interações: Cultura e Comunidade, v. 8, n. 14, p. 261-279, 2013.

ORTIZ, Renato. A Morte Branca do Feiticeiro Negro. São Paulo: Brasiliense, 1999.

PIRES, Flávia. O que as crianças podem fazer pela antropologia? Horizontes Antropológicos, v. 16 , n. 34,2010 , p. 137-157.

PÓLVORA, Jacqueline Brito. O Corpo Batuqueiro: Uma Expressão Religiosa Afro-Brasileira. In: LEAL, Ondina F. (Org.). Corpo e Significado. Ensaios de Antropologia Social. Porto Alegre: Editora da Universidade/UFRGS, 1995, p. 125-137.

PRANDI, Reginaldo. O Brasil com axé: candomblé e umbanda no mercado religioso. Estudos Avançados, v. 18, n. 52, p. 51-66, 2004.

RABELO, Miriam Cristina. Aprender a ver no Candomblé. Horizontes Antropológicos, v. 21, n. 44 , p. $229-251,2015$.

RABELO, Miriam Cristina; SANTOS, Rita Maria Brito. Notas sobre o aprendizado no Candomblé. Revista FAEEBA, v. 20, n. 35, p. 187-200, 2011.

RAFAEL, Ulisses Neves. Xangô rezado baixo: religião e política na Primeira República. São Cristóvão: Editora da Universidade Federal de Sergipe/Maceió: Editora da Universidade Federal de Alagoas, 2012.

RIBEIRO, René. Antropologia da Religião e outros Estudos. Recife: Editora Massangana, 1982.

SANTOS, Irineia Maria Franco. O Axé Nunca se Quebra: transformações históricas em religiões afrobrasileiras, São Paulo e Maceió (1970-2000). Maceió: EDUFAL - Editora da Universidade Federal de Alagoas, 2014.

SANTOS, Ronaldo Martins dos. AGBON: arte, beleza e sabedoria ancestral africana. Educação e pluralidade cultural. Salvador: Eduneb, 2008.

SARMENTO, Manuel J. As culturas da infância nas encruzilhadas da $2^{\text {a }}$ modernidade. In: SARMENTO, Manuel J; CERISARA, A. B. (orgs.). Crianças e miúdos: perspectivas sócio-pedagógicas da infância e educação. Porto: Asa, 2004, p. 9-34.

. A Reinvenção do Ofício de Criança e de Aluno. Atos de Pesquisa em Educação, v. 6, no. 3, 2011, p. 581-602.

TASSINARI, Antonella M. I. O que as crianças têm a ensinar a seus professores? Contribuições a partir da Antropologia. Antropologia em Primeira Mão, s/v, n. 130, p. 1-20, 2011.

WEBER, Max. Ensaios de sociologia. Rio de Janeiro: Guanabara, 1982.

Submetido em: 16-3-2017

Aceito em:13-11-2017 